\title{
IMPLEMENTASI APLIKASI SISTEM INFORMASI DAN ADMINISTRASI GURU AGAMA (SIAGA) DALAM MENINGKATKAN PELAYANAN ADMINISTRATIF DI SEKSI PENDIDIKAN AGAMA ISLAM (PAIS) KEMENTERIAN AGAMA KABUPATEN LAMONGAN
}

\author{
Sofi Fahmiani, Muhammad Tanwirul Qulub. Arif Mansyuri \\ UIN Sunan Ampel, Surabaya - Indonesia I sofifahmiani2@gmail.com
}

\begin{abstract}
Abstrak: Sistem informasi administrasi guru agama (SIAGA) merupakan sistem informasi manajemen atau aplikasi yang digunakan untuk mendata keberadaan guru agama dari tingkat TK sampai SMA/SMK atau lembaga pendidikan yang bernaungan dibawah KEMDIKBUD yang dalam hal ini khusus untuk guru pendidikan agama diambil oleh atau diatur oleh Kementrian Agama. Yang mana berfungsi untuk mendata seluruh guru pendidikan agama kemudian merekrutnya dengan memberangkatkan untuk pendidikan profesi guru (PPG) guna menjadi guru yang profesional (sertifikasi) sampai proses pendapatan tunjangan profesi guru (TPG). Tujuan dari penelitian ini adalah untuk mendeskripsikan implementasi aplikasi SIAGA dalam meningkatkan pelayanan administratif di seksi pendidikan agama islam kementrian agama kabupaten Lamongan. Rumusan masalah dari penelitian ini adalah bagaimana implementasi aplikasi SIAGA dalam membantu meningkatkan layanan administrasi bagi guru agam islam mulai dari jenjang TK sampai SMA khusunya di wilayah kabupaten Lamongan. Penelitian ini menggunakan pendekatan kualitatif. Metode penelitian yang digunakan adalah wawancara, observasi, dan dokumentasi. Data yang diteliti dalam penelitian ini melalui 3 tahap yaitu reduksi data, penyajian data, dan verifikasi. Hasil penelitian menunjukkan bahwa SIAGA sebagai basis pangkalan data guru pendidikan agama islam telah mampu digunakan secara maksimal meski masih ada data yang belum tercover di dalamnya. Dan penggunaan SIAGA harus memiliki koneksi dengan internet.
\end{abstract}

Keywords: sistem informasi manajemen, SIAGA, administratif 


\section{Pemdahuluan}

Pada saat ini dunia sedang berada dalam era digital. Pada era ini dicirikan dengan era komunikasi dan informasi berbasis teknologi komputer. Sejalan dengan berkembangnya teknologi, informasi kini menjadi sebuah sumber daya yang sangat penting. Sebagai individu, hampir seluruh waktu kita habiskan untuk mencari, menyimpan, atau bertukar informasi dari segala macam fasilitas teknologi yang kita miliki (Muhammad Anshar Akil, 2013:5)Perlu untuk kita disadari, bahwa informasi menjadi sumber daya yang sangat penting bagi diri kita maupun bagi organisasi. Oleh Karena itu, salah satu tuntutan utama bagi semua organisasi profesional adalah pengelolaan informasi yang semakin efektif sehingga organisasi itu dapat mencapai tujuannya.

Telah kita ketahui dan rasakan, dari Perkembangan teknologi informasi yang sangat pesat, menumbuhkan kesadaran dari berbagai pihak bahwa perkembangan dan terobosan teknologi informasi akan terus berlanjut di masa depan. Hal ini lantas menjadi tantangan dan ujian bagi setiap organisasi agar dapat memanfaatkan perkembangan teknologi tersebut, tidak terkecuali dalam dunia pendidikan. Dalam rangka menunjang tercapainya sasaran dan tujuan fungsi- fungsi operasional dalam dunia pendidikan sistem informasi manajemen Lembaga Pendidikan akan merasakan beberapa manfaat sebagai berikut:

- Tersedianya sistem pengelolaan data dan informasi Pendidikan,

- Terintegrasinya data dan informasi Pendidikan untuk mendukung proses pengambilan keputusan,

- Tersedianya data dan informasi Pendidikan yang lengkap bagi seluruh stakeholders yang berkepentingan dalam bidang Pendidikan.

- Tersedianya layanan administratif yang berbasis teknologi

Penerapan sistem informasi manajemen yang diterapkan dalam dunia pendidikan diantaranya adalah pengolahan data tenaga pendidik, data pendidik perlu diolah dengan baik karena pendidik menjadi salah satu komponen pendukung pelaksanaan 
penyelenggaraan pendidikan di sekolah/madrasah dan keberadaan pendidik menjadi bagian dari mutu lembaga pendidikan.

Seksi pendidikan agama islam di kementrian agama kabupaten lamongan adalah salah satu lembaga yang telah memanfaatkan sistem informasi manajemen dalam pengolahan data pendidik. Oleh karena itu penulis merasa tertarik untuk melakukan penelitian untuk melihat penerapan sistem informasi manajemen berupa aplikasi SIAGA dalam pengolahan data guru pendidikan agama islam di daerah lamongan. Didalam aplikasi SIAGA, diharapkan mampu mempermudah layanan administrasi bagi guru pendidikan agama dari pendataan awal hingga proses pemutaakhiran menjadi guru pendidikan agama, sertifikasi guru professional, pemberian tunjangan profesi guru dan lain-lain.

Dengan adanya sistem informasi berupa Aplikasi SIAGA, maka akan mempermudah pelayanan administratif di kementrian agama kabupaten lamongan. Yang mana pelayanan administratif adalah suatu kegiatan yang dilakukan oleh seseorang atau kelompok orang maupun suatu instansi tertentu untuk memberikan bantuan dan kemudahan kepada masyarakat yang mempunyai kepentingan dalam organisasi, dalam rangka mencapai tujuan sesuai dengan aturan pokok dan tata cara yang telah ditetapkan. Jika organisasi mampu memberikan pelayanan yang optimal dan memenuhi tuntutan dari masyarakat, maka dapat dikatakan organisasi tersebut telah mampu memberikan pelayanan yang memuaskan kepada masyarakat.

Penelitian ini berusaha menganalisis Implementasi Sistem Informasi dan Administrasi Guru Agama (SIAGA) dalam meningkatkan pelayanan administrasi di seksi Pendidikan Agama Islam Kementerian Agama Kabupaten Lamongan. Masalah yang ingin dijawab adalah bagaimana penggunaan Sistem Informasi dan Administrasi Guru Agama (SIAGA) sehingga mampu meningkatkan layanan administrasi guru Agama khususnya di Kabupaten Lamongan. 


\section{Metodologi}

Penelitian ini adalah penelitian lapangan (field research) yang bersifat kualitatif. Dengan metode pengumpulan data melalui wawancara, observasi dan dokumentasi. Teknik pengolahan data dan analisis data yang digunakan adalah reduksi data, penyajian data, verifikasi data dan penarikan kesimpulan. Untuk menguji keabsahan data dilakukan dengan teknik triangulasi dan member check.

\section{Hasil dan Pembahasan}

Manajemen merupakan proses perencanaan, pengorgasisasian, pengawasan, pengarahan dan lain-lain dalam suatu organisasi. Sedangkan informasi dalam satu organisasi adalah data yang diolah sedemikian rupa sehingga memiliki nilai dan arti bagi organisasi. Sistem Informasi Manajemen (SIM) merupakan sistem yang mengolah serta mengorganisasikan data dan informasi yang berguna untuk mendukung pelaksanaan tugas dalam suatu organisasi.

Sistem informasi manajemen dibedakan dengan sistem informasi biasa karena SIM digunakan untuk menganalisis sistem informasi lain yang diterapkan pada aktivitas operasional organisasi. Secara akademis, istilah ini umumnya digunakan untuk merujuk pada kelompok metode manajemen informasi yang bertalian dengan anotomasi atau dukungan terhadap pengambilan keputusan manusia, misalnya sistem pendukung.keputusan,sistem pakar, dan sistem informasi eksekutif.

Setelah tahun 2000'an, sistem informasi manajemen mulai berkembang sebagai satu sistem yang terintegrasi pada berbagai induk perusahaan dan cabang- cabangnya. Sistem tersebut kemudian dibentuk dalam sistem informasi berbasis komputer (Computer BasedInformation System). Hingga kini,sistem informasi berjalan secaraterintegrasi dan berjalan secaraotomatis. SIM sendiri mempunyai elemen-elemen fisik yang dibutuhkan untuk kelancaran sistem yang digunakan, yaitu perangkat keras komputer, perangkat lunak, serta program aplikasi. Selanjutnya, dalam SIM terdapat database dan prosedur pelaksanaan sistem 
manajemen perusahaan dan tentunya, petugas yang mengoperasikan semua sistem tersebut.

Tujuan dari Sistem Informasi Manajemen adalah menyediakan suatu informasi untuk pengambilan keputusan, dan menyediakan suatu informasi yang dipergunakan didalam suatu perencanaan, pengendalian, pengevaluasian, dan juga perbaikan berkelanjutan. Banyak sekali contoh penerapan sistem informasi manajemen salah satunya adalah Desicion Support System(DSS) yang mana sistem ini membantu para manajer dalam mengambil keputusan dengan cara mengamati lingkungan organisasi, seperi pendataan atau pendaftaran calon pegawai. Manfaat dari Sistem Informasi Manajemen yaitu untuk meningkatkan aksesbilitas data secara akurat dan tepat waktu bagi penggunanya. SIM inipun kemudian dimanfaatkan sebagai sarana dalam mengakses data maupun informasi secara online.

Pada tahun 2019, Kementerian Agama melalui Direktorat Pendidikan Agama Islam meluncurkan sebuah aplikasi yang diberi nama SIAGA. Kementerian Agama RI terus memberikan pelayanan dan kemudahan khususnya untuk Guru PAI yang berada di sekolah umum. Tentu kita tahu bahwa Guru PAI yang mengajar di sekolah umum terkadang mengalami ketidakjelasan nasib mereka pada pelaksanaan sertifikasi akibat dualisme birokrasi antara Departemen Pendidikan Nasional dan Depatemen Agama. Padahal, selama ini para guru agama di sekolah umum mendapat gaji dari dinas pendidikan kota/kabupaten, tetapi pada pelaksanaan sertifikasi justru diserahkan kepada Departemen Agama. Oleh karena itu, Kementerian Agama RI melalui Dirjen Pendis Direktorat PAI telah meluncurkan Aplikasi yang bernama SIAGA (Sistem Informasi dan Administrasi Guru Agama).

Aplikasi SIAGA memiliki fungsi untuk menverifikasi dan Validasi data Guru dan Pengawas PAI diseluruh Indonesia. Bagi operator sekolah pada satuan pendidikan yang pada sekolahnya terdapat guru agama, maka wajib mengisi beberapa data yang perlu diverifikasi dan divalidasi atau istilahnya Verval. 
Aplikasi SIAGA akan digunakan sebagai data dasar dalam program Direktorat Pendidikan Agama Islam seperti Verval, Sertifikasi, Pembayaran TPG, dan lainnya.

Di Kementerian Agama Kabupaten Lamongan juga telah menggunakan aplikasi SIAGA dalam mempermudah pelayanan administrasi guru agama di kabupaten Lamongan. Untuk pengoperasian aplikasi SIAGA dibutuhkan operator yang bisa menghandlenya, dalam hal ini dipegang oleh Bapak Safuan Hadi di seksi Pendidikan Agama Islam (PAIS). Terlebih dahulu operator login dengan akun yang telah dibuat.

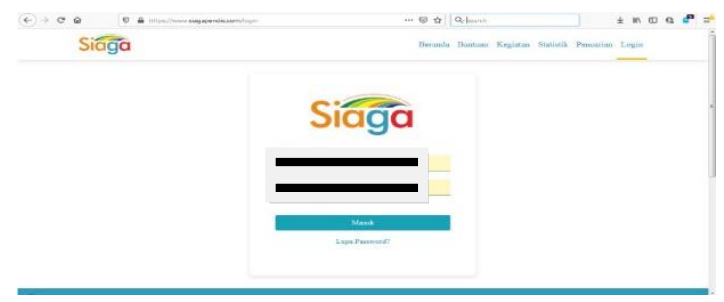

Gambar 01. Login Akun SIAGA

Ada beberapa menu yang ada di Aplikasi SIAGA

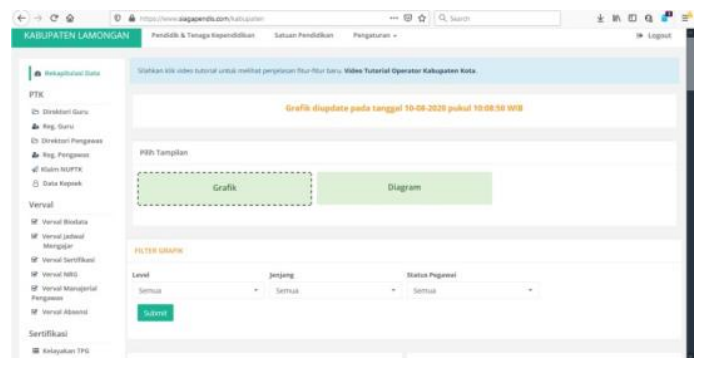

Gambar 02. Fitur Aplikasi SIAGA

- PTK

Dalam menu ini terdapat submenu :

- Direktori Guru yang berisi daftar guru di Kabupaten Lamongan. 
- Reg. Guru yang artinya operator bisa menambahkan data guru PAI di Kabupaten Lamongan.

- Direktori Pengawas yang berisi daftar pengawas di Kabupaten Lamongan.

- Reg. Pengawas yang artinya operator bisa menambahkan data pengawas PAI di Kabupaten Lamongan.

- Klaim NUPTK yang berisi pengajuan NUPTK.

- Data Kepsek yang berisi daftar GPAI yang menjadi Kepala sekolah untuk proses pengangkatan/pemberhentian.

- Verval

Dalam menu ini terdapat submenu :

- Verval Biodata yang berisi daftar GPAI dan Pengawas yang mengajukan Verval Biodata.

- Verval Jadwal Mengajar yang berisi daftar GPAI dan Pengawas yang mengajukan Verval jadwal mengajar dan tugas tambahan.

- Verval Sertifikasi yang berisi daftar GPAI dan Pengawas yang mengajukan Verval data sertifikasi.

- Verval NRG yang berisi daftar GPAI dan Pengawas yang mengajukan Verval data NRG.

- Verval Manajerial Pengawas yang berisi daftar pengawas yang verval manajerial.

- Verval Absensi yang berisi daftar guru dan pengawas yang verval absensi.

- Sertifikasi

Dalam menu ini terdapat submenu :

- Kelayakan TPG yang berisi daftar tunjangan profesi guru.

- Dispensasi berisi daftar dispensasi guru dalam kelengkapan data untuk pencairan TPG.

- SK pencairan yang berisi daftar nomor dan tanggal SK pencairan.

- Laporan TPG yang berisi laporan tunjangan profesi guru berdasarkan tahun anggaran.

- Kekurangan Anggaran

Dalam menu ini terdapat submenu : 
- PNS yang berisi daftar kekurangan anggaran PNS.

- GBPNS Non Inpassing yang berisi daftar kekurangan anggaran GBPNS belum Inpassing.

- GBPNS Inpassing yang daftar kekurangan anggaran GBPNS Inpassing.

- Report yang berisi laporan kekurangan anggaran yang datanya bisa diunduh.

Selain itu terdapat juga secara detail data statistik mengenai jumlah guru berdasarkan :

- Jenis kelamin

- Status pegawai

- Kualifikasi pendidikan

- Instansi yang mengangkat

- Golongan

- Sertifikasi

- Jenjang pendidikan satminkal

- Perkiraan pensiun

- Status satminkal

- NRG dan NUPTK

- Gaji pokok

- Keaktifan

- Status

- Jenjang

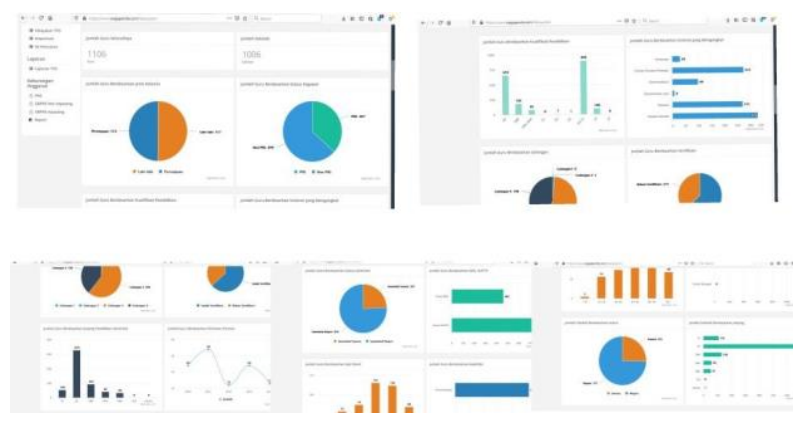

Gambar 03. Data Statistik Guru PAI 
Dengan penerapan sistem informasi manajemen, akan sangat mempermudah dalam pelayanan administratif kantor. Yang mana pelayanan administratif ialah suatu perencanaan, pengendalian, dan pengorganisasian pekerjaan pada sebuah perkantoran serta menjadi penggerak kepada mereka yang menjalankannya agar tujuan yang telah ditetapkan dapat tercapai. Hal atau sasaran yang terkena oleh rangakaian kegiatan itu pada umumnya ialah pekerjaan perkantoran(office work) yang meliputi kegiatan mengetik, menghitung, memeriksa, menyimpan, menggandakan, mengirim surat, mencatat dan juga menyortir. Pelayanan administratif ini dibutuhkan untuk membantu dalam menyelesaikan pekerjaan dasar organisasi.

Pada dasarnya pelayanan adalah suatu kegiatan yang ditawarkan oleh organisasi atau perorangan kepada konsumen yang dilayani yang bersifat tidak berwujud dan tidak dimiliki. Dari pengertian di tersebut tersirat bahwa suatu pelayanan melibatkan dua pihak yang saling berhubungan yaitu organisasi pemberi pelayanan di satu pihak dan masyarakat sebagai penerima pelayanan di pihak lainnya. Pelayanan administrasi perkantoran ini merupakan suatu perencanaan, pengendalian, dan pengorganisasian pekerjaan pada sebuah perkantoran serta menjadi penggerak kepada mereka yang menjalankannya agar tujuan yang telah ditetapkan dapat tercapai. Tujuan pelayanan administrasi perkantoran ialah :

- Menyediakan data dan informasi secara lengkap kepada pihakpihak yang membutuhkan untuk pelaksanaan tugas organisasi secara efektif dan efisien

- Menerapkan kebijakan perusahaan atau departemen dan memerikan standar pelayanan dalam kaitannya dengan manajemen

- Melakukan verifikasi, pemantauan, serta evaluasi kerja dengan membuat laporan terkait kegiatan yang dilakukan

Jika organisasi mampu memberikan pelayanan yang optimal dan memenuhi tuntutan dari masyarakat, maka dapat dikatakan organisasi tersebut telah mampu memberikan pelayanan yang memuaskan kepada masyarakat. 
Dalam upaya meningkatkan kualitas layanan tentunya harus memperhatikan fungsi-fungsi administrasi perkantoran modern yang terdiri dari :

- Fungsi Manajerial

Dalam menjalankan suatu organisasi pelayanan tentunya membutuhkan prosedur kerja yang jelas. Prosedur kerja yang sering dijumpai disetiap organisasi publik maupun organisasi profit adalah standar operasional prosedur (SOP). Akan tetapi, pelaksanaan operasional yang dilakukan tidak sesuai dengan harapan. Oleh karena itu, dibutuhkan sinkronisasi SOP yang disampaikan dengan pelayanan yang diberikan kepada penerima layanan.

- Fungsi Interpersonal

Fungsi yang membutuhkan penilaian dan analisis sebagai dasar pengambilan keputusan serta keterampilan berhubungan dengan orang lain,seperti mengkoordinasikan tim. Sedangkan menurut Salam (2014) menyatakan bahwa fungsi interpersonal berkenaan dengan pemanfaatan teknologi dalam memberikan pelayanan. Oleh karena itu, dalam proses pelayanan tidak hanya dalam dilihat di lapangan akan tetapi dapat disingkronisasikan dengan internet. Sehingga pihak pemberi layanan dan penerima layanan mampu berkoordinasi dengan baik, tanpa ada batas yang menghalangi.

- Fungsi Teknis

Fungsi yang membutuhkan pendapat, keputusan dan keterampilan perkantoran yang memadai seperti familieritas dengan beberapa software. Berdasarkan pendapat tersebut, memberikan gambaran bahwa dalam pelaksanaan pelayanan publik dibutuhkan sebuah sistem yang terintegerasi dengan sistem lainnya. Seperti halnya dalam proses pelayanan membutuhkan sebuah sistem yang terintegrasi dengan data atau informasi yang lengkap. Sehingga pada saat melakukan pengecekan data atau informasi dapat dieroleh dengan cepat.

- Fungsi Rutin

Fungsi yang membutuhkan pemikiran minimal seperti pencatatan, pendokumentasian, pengarsipan, dan lain-lain. Berdasarkan pendapat tersebut, memberikan informasi bahwa, 
dalam memberikan data atau informasi yang akurat, cepatdan aktual. Maka dibutuhkan sebuah sistematisasi penyimpanan yang terprogram. Sehingga pada saat pencarian data atau informasi maka akan dapat diperoleh.

- Fungsi Analisis

Fungsi yang membutuhkan pemikiran yang kritis dan kreatif disertai kemampuan untuk mengambil keputusan, seperti membuat dan menganalisis laporan maupun membuat keputusan. Berdasarkan pendapat di atas, menjelaskan bahwa dalam proses pelaksanaan suatu organisasi tentunya mengalami sebuah kendalakendala yang harus diselesaikan. Oleh karena itu, dibutuhkan sebuah analisis setiap permasalahan yang muncul berdasarkan fakta, data dan informasi yang akurat. Sehingga dalam proses pengambilan keputusan tidak akan mengalami kendala yang begitu berarti.

Dari kelima fungsi pelayanan administrasi diatas, maka selaras dengan pelayanan administratif yang ada di seksi PAIS Kementerian Agama Kabupaten Lamongan. Ini dibuktikan dengan adanya SOP, pegarsipan data guru dan pengawas PAI, penginputan data dengan sistem informasi manajemen dan lain sebagainya. Pelayanan administratif di seksi PAIS tidak hanya berkaitan dengan arsip maupun data yang direkap. Namun pelayanan konsultasi mengenai guru agama yang ingin mendaftar akun SIAGA pun dilayani dengan baik. Ini berarti fungsi interpersonal telah berfungsi didalam pelayanan administratif kantor kementerian agama kabupaten Lamongan.

Ada bebrapa faktor yang perlu diperhatikan dalam peningkatan pelayanan publik menurut Tilaar (2001:57) ialah :

- Dedikasi dan disiplin

Untuk memberikan sebuah pelayanan bermutu pada seorang manusia haruslah mempunyai rasa pengabdian terhadap tugas dan pekerjaannya. Dalam artivisi yang merupakan target proses pelayanan harus normatif dan idealis. Sebab seorang yang memiliki dedikasi tinggi adalah manusia yang menyadari arti sebuah profesinya sendiri dan berusaha untuk mewujudkannya.

- Jujur 
Kejujuran profesionalisme akan menghasilkan produk yang unggul dan terus-menerus dapat bersaing. Sikap profesionalisme ini ditandai oleh seorang manusia unggul yang mengetahui kapan dia berdiri sendiri dan kapan dia harus bekerja sama.

- Tekun

Seorang manusia unggul adalah seorang yang memfokuskan perhatian pada tugas dan pekerjaan yang telah diserahkan kepadanya atau suatu usaha yang sedang dikerjakannya. Ketekunan akan menghasilkan sesuatu karena manusia unggul tidak akan berhenti sebelum ia membuahkan sesuai dengan kehidupan yang mementingkan mutu.

- Sumber Daya Manusia

Sumber Daya Manusia merupakan aset yang dimiliki oleh instansi atau organisasi swasta maupun pemerintahan. Tanpa adanya dukungan sumber daya manusia yang handal dan professional aktivitas suatu kantor akan memberikan dampak yang sangat signifikan terhadap perkembangan atau pelayanan suatu organisasi.

- Kepemimpinan

Merupakan salah satu kunci dalam menentukan terciptanya efisiensi dan efektifitas kerja, serta peningkatan kerja bawahan. Pimpinan dapat berhasil mengelola suatu organisasi yang dikelolanya bila pimpinan yang dimaksud dapat berperan dengan baik. Seorang pemimpin harus melakukan kegiatan dalam hal membimbing, mengarahkan perilaku bawahannya pada suatu tujuan tertentu.

Dari faktor-faktor diatas, diperoleh fakta di lapangan bahwa pelayanan administratif di seksi PAIS berjalan dengan baik. Ini artinya bahwa dedikasi dan kedisiplinan tertanam di pribadi masing-masing pegawai. Mereka melayani dengan sepenuh hati apapun yang berkaitan dengan keperluan administratif kantor. Kejujuran pun diterapkan oleh paara pegawai, ini dibuktikan dengan adanya tunjangan profesi guru yang harus dicairkan dan memberikan laporan keuangan secara detail. Di seksi PAIS pun memiliki SDM yang handal dan profesional, yang mana segala data dan informasi dikelola dengan baik menggunakan sisitem informasi 
manajemen maupun secara manual. Kepemimpinan yang di pimpin oleh kepala seksi PAIS Bapak Masduki Yasin juga menciptakan kinerja yang efektif dan efisien dengan memberikan bimbingan dan mengarahkan bawahannya.

. Dengan adanya aplikasi SIAGA, pelayanan administratif di seksi PAIS sangat mudah dijalankan. Karena dengan adanya sistem tersebut, maka mempermudah dalam upload data yang mana seorang guru tidak perlu datang ke kantor Kemenag. Mereka hanya perlu aktif dalam upload data di sistem informasi dan administrasi guru agama(SIAGA). Dan dengan adanya aplikasi SIAGA juga meminimalisir dokumen yang bertumpuk banyak di kantor. Ditambah lagi dengan cara pengoperasiannya yang mudah dipahami dan dijalankan, ini berarti pelayanan administratif juga mudah untuk dilaksanakan.

Seperti contoh pelayanan bagi guru agama yang akan diberangkatkan PPG juga dipermudah dengan adanya aplikasi SIAGA. Di aplikasi tersebut secara lengkap data guru mulai dari SK, sampai penilaian kinerja guru. Tidak hanya itu saja, di aplikasi SIAGA juga berisi kelayakan Tunjangan Profesi Guru (TPG). Yang mana jika guru agama ingin mendapatkan TPG maka harus upload surat keterangan melakasanakan tugas(SKMT) yang nantinya akan diverifikasi oleh operator. Pada intinya semua layanan administratif terbantu sekali dengan adanya aplikasi SIAGA. Sejauh ini kendala yang dirasakan oleh operator hanya masalah guru yang mungkin tidak begitu aktif untuk upload data di akun SIAGA, sehingga akun tersebut bisa dinonaktifkan.

\section{Kesimpulan}

Sistem Informasi Manajemen (SIM) merupakan sistem yang mengolah serta mengorganisasikan data dan informasi yang berguna untuk mendukung pelaksanaan tugas dalam suatu organisasi. Bentuk dari sistem informasi manajemen yang dilakuakan di seksi PAIS Kementerian Agama Kabupaten Lamongan adalah Sistem Informasi dan Administrasi Guru Agama atau yang sering disebut SIAGA. Dalam upaya meningkatkan pelayanan administratif di seksi PAIS, digunakanlah aplikasi SIAGA yang mana telah menjadikan solusi bagi para administrator 
dalam mempermudah pelayanan administrasi. Diketahui bahwa aplikasi SIAGA memiliki fungsi untuk menverifikasi dan Validasi data Guru dan Pengawas PAI di seluruh Indonesia. Dengan mengimplementasikan aplikasi SIAGA yang disertai berbagi fitur dan menunya, maka pelayanan administratif di seksi PAIS berjalan dengan lancar. Adapun pelayanan administratif melalui aplikasi SIAGA adalah registrasi dan pendataan guru PAI, merekrut guru untuk melakukan PPG, memvalidasi data guru serta pencairan tunjangan profesi guru. Semuanya secara otomatis meggunakan aplikasi SIAGA yang dipegang oleh operator di seksi PAIS Kementerian Agama Kabupaten Lamongan.

Telah diketahui juga bahwa kendala yang ada di seksi PAIS dalam pelayanan administratif melalui aplikasi SIAGA adalah tentang Guru agama yang kurang update, mungkin karena faktor usia atau yang lainnya sehingga mereka kurang update. Oleh karena itu penulis menyarankan kepada seluruh pegawai terutama Kepala seksi PAIS agar lebih sering mengadakan sosialisasi maupun workshop kepada para guru PAI khususnya mereka yang kurang update dalam melakukan pendataan melalui aplikasi SIAGA, agar data guru di seluruh kabupaten lamongan tetap akurat tanpa adanya akun yang dinonaktifkan.

\section{References}

Abdussamad, Yuriko. "Sistem Pelayanan Administrasi." Jurnal Fakultas Ekonomi dan Bisnis (2019) : 1-2

Akil, M. A. Sistem Informasi Manajemen: Strategi Mengelola Organisasi Profesional di Era Digital. Makassar: Alauddin Press, 2013.

Salam, Rudi. "Penerapan Fungsi Administrasi Perkantoran Modern Berbasis Daya Saing Organisasi dalam Menyongsong MEA 2015." Jurnal Seminar Nasional. Fakultas Ilmu Sosial Universitas Negeri Makassar (2015) 186-187

Slamet, Hariyanto. "Sistem Informasi Manajemen." Jurnal Publiciana Vol 9 No.1 (2016) : 81-82 
Sukoco M, Badri. Manajemen Administrasi Perkantoran Modern. Surabaya:

Erlangga, 2007. 2-3

http://abdiguru.id/siaga-pendis-kemenag-aplikasi-verval-guru-danpengawas-pai/ di akses pada 14 Oktober 2020. 